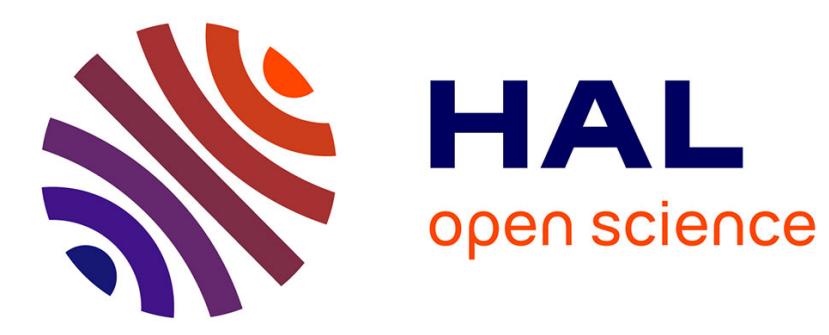

\title{
Humus Index as an indicator of forest stand and soil properties
}

Jean-François Ponge, Richard Chevalier

\section{To cite this version:}

Jean-François Ponge, Richard Chevalier. Humus Index as an indicator of forest stand and soil properties. Forest Ecology and Management, 2006, 233 (1), pp.165-175. 10.1016/j.foreco.2006.06.022 . hal-00495387

\section{HAL Id: hal-00495387 \\ https://hal.science/hal-00495387}

Submitted on 25 Jun 2010

HAL is a multi-disciplinary open access archive for the deposit and dissemination of scientific research documents, whether they are published or not. The documents may come from teaching and research institutions in France or abroad, or from public or private research centers.
L'archive ouverte pluridisciplinaire HAL, est destinée au dépôt et à la diffusion de documents scientifiques de niveau recherche, publiés ou non, émanant des établissements d'enseignement et de recherche français ou étrangers, des laboratoires publics ou privés.

\section{(이) $\$$}

Distributed under a Creative Commons Attribution - NonCommercial - NoDerivatives| 4.0 


\section{Humus Index as an indicator of forest stand and soil properties}

1 Muséum National d'Histoire Naturelle, CNRS UMR 5176, 4 avenue du Petit-Château, 91800 Brunoy, France

2 Cemagref, Unité de Recherche "Écosystèmes Forestiers", Domaine des Barres, 45290 Nogent-sur-Vernisson, France

\section{Abstract}

12

The Humus Index, based on the visual assessment of topsoil horizons and a classification of humus forms, is a numerical score which can be used as a correlate of stand and soil properties. In oak stands from the Montargis forest (Loiret, France) we observed a good linear relationship of the Humus Index with most parameters describing stand development (age, basal area, height and diameter at breast height of dominants) and soil type (depth of clay horizon). The relationship with parameters describing nutrient availability 19 (exchangeable bases, base saturation) was similarly good but non-linear. In the studied forest the Humus Index was affected first by stand age and second by soil type. When corrected for age and soil type, data (96 pooled estimates) indicated a slight decrease in the Humus Index (shift towards more active humus forms) in stands converted from old coppices-with-standards when compared with even-aged high forest.

Keywords: Humus forms; Stand development; Management practices; Soil types; Oak stands; Coppices-with-standards; Even-aged high forests

\footnotetext{
* Corresponding author. Tel.: +33 1 60479213; fax: +33 160465009 .

E-mail address: jean-francois.ponge@wanadoo.fr (J.F. Ponge).
} 


\section{Introduction}

There is a growing need for synthetic indicators to be used for the wide scale monitoring of terrestrial ecosystems, in particular when threatened by pollution, climate change and human pratices (Moore and DeRuiter, 1993; Lindenmayer et al., 2000; Duelli and Obrist, 2003). This goal can be achieved through field measurements if (i) they can be done by untrained people and (ii) field data are correlated with a lot of ecosystem parameters indicative of woodland well-being.

Humus forms (Mull, Moder, Mor) indicate the rate at which nutrients are circulating within terrestrial ecosystems (Ovington, 1965; Chapin et al., 1986; Ponge, 2003). They vary according to climate and parent rock (Vitousek et al., 1994; Ponge and Delhaye, 1995;

14 Sadaka and Ponge, 2003), but also to canopy and understory vegetation (Beniamino et al., 1991; Muys et al., 1992; Aubert et al., 2004), stand age (Emmer and Sevink, 1994; Sagot et al., 1999; Aubert et al., 2004), management (Aber et al., 1978; Terlinden and André, 1988; Covington, 1981), fertilization (Toutain et al., 1988; Deleporte and Tillier, 1999), irrigation (Vavoulidou-Theodorou and Babel, 1987) and pollution (Coughtrey et al., 1979; Kuperman,

19 1996; Gillet and Ponge, 2002). In turn, humus forms, by their focus position within biogeochemical cycles, influence many ecosystem compartments and processes such as

21 ground flora (Le Tacon and Timbal, 1973; Klinka et al., 1990; Bartoli et al., 2000), regeneration of forest canopy species (Bernier and Ponge, 1994; Bernier, 1996; Ponge et al., 1998), forest productivity (Delecour, 1978) and litter quality (Davies et al., 1964; Toutain and

24 Duchaufour, 1970). They are considered, together with ground vegetation, as an indicator of 25 the soil nutrient regime (Wilson et al., 2001) and we expect them to be the best predictor of 26 stability domains within ecosystems (Odum, 1969; Ulrich, 1987; Ponge, 2003). However, the 27 wider use of humus forms as a site factor is limited by subjectivity in the identification of 
1 forest floor and topsoil horizons (Federer, 1982) and by the existence of small-scale variation

2 (Riha et al., 1986; Carter and Lowe, 1986; Torgersen et al., 1995).

3

4

The Humus Index has been designed for the transformation of a scale of discrete humus forms in a numerical parameter, which could be manipulated statistically (Ponge et al., 2002; Ponge et al., 2003; Fédoroff et al., 2005). In the abovementioned studies the Humus Index proved to be significantly correlated with some important ecological parameters of forest ecosystems such as topsoil physical and chemical properties and plant and soil animal communities.

In forests, stand and soil properties are of paramount importance for the management and choice of target tree species (Carmean, 1975; Miller, 1981; Muys and Lust, 1992) and for the assessment of health and productivity of the ecosystem (Christie and Lines, 1979; Ulrich 1994; Ponge et al., 1997). The present study was intended to correlate the Humus Index with parameters of stand and soil development under varying management regimes of the same canopy species.

\section{Study sites}

The Montargis forest (Loiret, France) is a state forest (4090 ha) located in the northern half of France (Fig; 1), in the rainwater basin of river Seine. The general aspect is fairly level, with a slight westward declivity, the altitude varying between 95 and $132 \mathrm{~m}$. The climate is oceanic, with a weak continental influence. The mean annual precipitation, calculated over the last thirty years, is $650 \mathrm{~mm}, 50 \%$ of which falling as rain during the growing season, from early April to late September. The mean temperature, calculated over the same thirty-year period, is $10.9^{\circ} \mathrm{C}$, with a minimum monthly mean of $3.7^{\circ} \mathrm{C}$ in January and a maximum monthly mean of $19.0^{\circ} \mathrm{C}$ in July. The parent rock is Senonian chalk (late Cretaceous), covered with postglacial (Holocene) deposits of variegated textural properties, 
1 sand being dominant in the western part and silt in the eastern part. This is at the origin of a

2 variety of soil types, weakly acidic to acidic, with a depth of 40 to $70 \mathrm{~cm}$, generally well-

3 drained year-round or at worst with weak temporary water-logging during Winter. Most

4 variation occurs through changes in the vertical distribution of particle size, in particular the depth at which clay becomes dominant varies to a great extent, ranging from 30 to $80 \mathrm{~cm}$ in 6 our data set.

7

\section{8}

The Montargis forest exhibits a compact shape, extending around the Paucourt village (Fig. 1), without any change in surface area and tree composition since the 12e century (Garnier, 1965). Coppice-with-standards, with sessile oak [Quercus petraea (Mattus.) Liebl.] standards and hornbeam (Carpinus betulus L.) coppices, was the dominant management type from 1670 on. The cutting period for coppices was first fixed to 70 years then to 25,40 or 50 years (according to site conditions) from 1783 on. Since 1857, coppiceswith-standards were partly converted to oak-dominated stands, with some admixture of beech (Fagus sylvatica L.) and hornbeam according to the sites. The conversion was total from 1872 on. Even-aged oak stands were issued from seed from the original mixed stands, oldest ones being 99 years-old, without any agricultural past nor plantation.

Ninety-six stands were selected, in order to embrace the variety of oak stands growing on medium acidic, well-drained sandy loam with level aspect, with one sampling area in each stand. All soils are luvisols according to FAO classification, varying according to the depth of the argillic horizon. The sampling area was selected in homogeneous vegetation and stand structure, beyond $50 \mathrm{~m}$ of stand limit. The choice of a restricted array of site conditions was aimed at testing the influence of stand properties. The sampling design was balanced according to 8 forest types, either even-aged high forest or conversion from previous coppice-with-standards: 
- FG35: even-aged high forest 35 years-old (12 stands)

- FG50: even-aged high forest 50 years-old (12 stands)

- FG90: even-aged high forest 90 years-old (12 stands)

- CS1: coppice-with-standards converted to medium-diameter regular stand (19 stands)

- CS2: coppice-with-standards converted to large-diameter regular stand (14 stands)

- CS3: coppice-with-standards converted to irregular stand (15 stands)

\section{Methods}

In each sampling area the Humus Index was visually assessed in triplicate at four plots, located at $14 \mathrm{~m}$ from the central post in the four main directions. At each plot three replicated estimates of the Humus Index were made at angles of a one-meter side equilateral triangle. The twelve measurements were averaged, giving a composite value for the sampling area, which could smooth out two scales of the local variation not directly related to stand properties (Riha et al., 1986; Ponge et al., 2002). The Humus Index was based on the classification of humus forms by Brêthes et al. (1995), modified by Jabiol et al. (2000): Eumull $=1$, Mesomull $=2$, Oligomull $=3$, Dysmull $=4$, Hemimoder $=5$, Eumoder $=6$, Dysmoder $=7$.

At each of the four plots within the same sampling area, a probe was used to measure the depth at which clay enrichment was found for the first time and the depth at which clay was dominant. The four values were averaged for each sampling area. At each of the four plots a soil sample was taken at $15-20 \mathrm{~cm}$ depth, then the four samples were pooled then air-dried for laboratory analyses on the fraction less than $2 \mathrm{~mm}$ : particle size distribution (clay, silt, sand), $\mathrm{pH}_{\text {water, }} \mathrm{pH}_{\mathrm{kCl}}$, cation exchange capacity, main exchangeable bases (extracted at soil $\mathrm{pH}$ using cobaltihexamine), and base saturation. Analytical methods followed ISO standards (Anonymous, 1999). 
At each sampling area we noted the time elapsed from the last thinning operation (except for clear-cuts), the age of the stand (only for even-aged high forest), we measured

4 the height and diameter at breast height of three dominant trees distant from less than $14 \mathrm{~m}$

5 from the central post, and we estimated the wood standing crop, using production tables by

6 Dagnélie et al. (1999). At each plot we measured the basal area (BA), the percent basal area occupied by beech, the percent basal area occupied by hornbeam. These four values were averaged for each sampling area.

The statistical treatment of the data involved regression analysis, using the Humus Index as a predicted (dependent) variable and several stand and soil properties as explanatory (independent) variables (Sokal and Rohlf, 1995). The analyses were performed with the StatBox® software. Residuals were tested for normality previous to analysis.

\section{Results}

The Humus Index exhibited a significant $(P<0.05)$ to highly significant $(P<0.001)$ correlation with 17 out of 21 stand and soil properties in oak stands of the Montargis forest (Table 1). Other stand and soil parameters did not reach such a high level of indication, as measured by the number of significant coefficients. For instance $\mathrm{pH}_{\text {water }}$ was significantly correlated with only 4 out of 8 stand measurements (against 7 our of 8 for Humus Index) and with only 8 out of 12 soil measurements (against 10 out of 13 for Humus Index). The best predicted variable was the age of even-aged high forest $\left(r=0.73, P=5.10^{-9}\right)$. Among soil parameters, Humus Index predicted the best base saturation $\left(r=-0.61, P=6.10^{-11}\right)$.

The Humus Index increased in value with the age of stands, indicating a shift from Mull to Moder in the course of time (Fig. 2), but it was not seemingly influenced by thinning operations $(r=0.10, P=0.18$, Table 1$)$. It should be noted that $\mathrm{pH}_{\text {water, }}$ on the contrary, was 
1 negatively correlated with the time elapsed from the last thinning operation $(r=-0.27$,

$2 \mathrm{P}=0.006)$. In short, after each thinning operation, soil acidity decreased then increased again

3 but without any concomitant change in the humus form.

4

These global trends were depicted by the whole set of sampling areas, without any account to possible effects of management pratices. If we separate even-aged high forest stands from stands converted from old coppices-with-standards, a more variegated landscape appears (Fig. 3).

The positive correlation between Humus Index and dominant height was better depicted by even-aged high forest (Fig. 3b) than by the whole set of oak stands (Fig. 3a). Coppices-with-standards did not exhibit any such trend, all of them falling within the range of even-aged high forest stands with tallest trees as dominants. A comparison by paired t-test between actual and calculated values of Humus Index for coppices-with-standards (using equation 1) did not reveal any departure from the trend exhibited by even-aged high forest, provided trees are of the same height $(t=0.89, P=0.19)$. Thus the relationship between Humus Index and dominant height was not affected by management practices.

A quite different picture was exhibited by dominant diameter. Similar to dominant height, the correlation between Humus Index and dominant diameter was positive, better depicted by even-aged high forest than by the whole set of stands, and null for coppiceswith-standards (Figs. 3c and 3d). However, Humus Indices measured in coppices-withstandards differed by more than one unit from values calculated using equation 1 derived for even-aged high forest $\left(\mathrm{t}=7.48, \mathrm{P}=2.10^{-9}\right)$. Thus, provided they had the same dominant diameter, coppices-with-standards seemed to exhibit more active humus forms than evenaged high forest. However, when comparing Figures $2 b$ and $2 d$ it appears that coppices-withstandards, the dominants of which have the same height than tallest trees of even-aged high forest (90 years-old, see Fig. 2), exhibit larger diameters at breast height, which flaws any 
1 comparison based on diameter. Coppices-with-standards, the mean diameter of dominant

2 trees is $45 \mathrm{~cm}$, should compare with even-aged high forest stands with a mean diameter of $3 \quad 35 \mathrm{~cm}$ for dominants.

4

Wood standing crop was estimated using both diameter and height of trees. If we consider wood volume and Humus Index, most coppices-with-standards fell within the range of tallest even-aged high forest stands (also oldest, $r=0.98, P=2.10^{-32}$ ), but some coppiceswith-standards exhibited higher volumes of wood and lower Humus Indices than expected on the base of even-aged high forest (Figs. 3e and 3f). However, a comparison between observed and calculated values of the Humus Index for coppices-with-standards did not reveal any significant shift $(t=1.17, P=0.12)$. Here too, there was no effect of management practices.

3
displayed a positive correlation with the Humus Index (Fig. 3g). Most coppices-withstandards fell within the range of variation of even-aged high forest stands (Fig. 3h) but they exhibited a higher Humus Index than expected from their basal area $\left(t=-4.96, P=5.10^{-6}\right)$. Beech and hornbeam (in percent of the total basal area) were positively correlated with the Humus Index, but at a lower level of significance than age, height, diameter and basal area (Table 1).

There was a positive relationship between the Humus Index and the depth at which clay becomes dominant (Fig. 4a): the shallower was the clay horizon, the lower was the Humus Index (Mull). Both even-aged high forest and coppices-with-standards exhibited the same relationship (Fig. 4b), with a similar slope of the regression line $(t=1.52, P=0.13)$. This figure may also help to verify that even-aged high forest and coppices-with-standards grew on the same range of soil conditions, thus comparisons between management pratices were not biased by a possible influence of the soil type. When the combined effect of stand age 
1 and soil type (expressed by depth of clay horizon) on the Humus Index of full-gown stands

2 was analysed by multiple regression, the mixed model explained $70.1 \%$ of the total variation,

3 shared between $52.9 \%$ for age and $17.2 \%$ for soil type.

4

For the same depth of clay horizon, coppices-with-standards exhibited a higher 6 Humus Index than the even-aged high forest $\left(t=7.13, P=5.10^{-9}\right)$, the difference being ca. 1 unit. However, since the group of even-aged high forest stands included young stands with more active humus forms (lower Humus Index), a possible bias due to aging was questioned.

9 If a Humus Index could be extrapolated for young stands supposed at the age of 90-years, then more valid comparisons between coppices-with-standards and even-aged high forest would be made. We used the equation shown in Figure 2 to extrapolate Humus Indices at 90 12 years $\left(\mathrm{HI}_{90}\right)$ from actual values of young stands $(\mathrm{HI})$, according to the formula $13 \mathrm{HI}_{90}=\mathrm{HI}+0.03(90$-age $)$, with the age of the stand expressed in years. The Humus Index thus 14 calculated for theoretical 90-years-old even-aged high forest remained significantly (and positively) explained by the depth of clay horizon $\left(R^{2}=0.37, P=10^{-4}\right)$. When even-aged high forest stands were thus corrected for aging, coppices-with-standards exhibited a lower Humus Index (ca. 0.5 unit less) than even-aged high forest $\left(t=3.8, P=2.10^{-4}\right)$, for the same soil conditions (expressed by depth of clay horizon).

The Humus Index showed a negative relationship with exchangeable Ca (fig. 4c), but, 21 contrary to above mentioned parameters, a better fitness was obtained with logarithmic values of calcium concentrations $\left(R^{2}=0.53\right.$ against 0.26 for linear regression). Even-aged high forest and coppices-with-standards exhibited the same relationship (Fig. 3d), and for the same concentration of exchangeable $\mathrm{Ca}$ the Humus Index did not differ between them $(t=0.06, P=0.48)$ 
Similarly, the relationship between Humus Index and base saturation was non-linear

(Fig. 4e) and was depicted both by even-aged high forest and coppices-with-standards (Fig. 4f), which did not differ between them at a given level of base saturation ( $t=0.017, P=0.49$ ).

\section{Discussion}

6

First, it should be highlighted that our Humus Index differs to a great extent from the same notation recently used by other authors to describe humus quality (Godefroid et al., 2005). The Humus Index they used was based on floristic composition, by averaging scores of different plant species pertaining to the same plant community. The scores were calculated on the model of Ellenberg (1974) indices, by noting the presence of plant species along a scale of humus forms, which were given a number as in our own method. In the present study, as in previously published papers (Ponge et al., 2002; Ponge et al., 2003; Fédoroff et al., 2005), the Humus Index was directly derived from the observation of humus forms, not of flora. Several authors noted that Ellenberg indices should be used with caution, given the existence of regional and temporal changes in ecological requirements of plant species (Parrish and Bazzaz, 1985; Hill et al., 1999; Diekmann and Lawesson, 1999). We suggest that the identification of the humus form (Green et al., 1993; Brêthes et al., 1995), which can be used directly on the field for building a Humus Index, should be preferred to a list of plant species.

The positive correlation between the Humus Index and the age of oak stands (Fig. 2) can be attributed to changes in humus forms and associated parameters (soil acidification, organic matter accumulation) which have been repeatedly observed to occur during crop rotation (Adam, 1999; Aubert et al., 2004; Godefroid et al., 2005). The passage from Mull (Humus Index 1-4) to Moder (Humus Index 5-7) accompanies the growth of trees and their increasing influence on the soil, more especially when their litter is poor in nutrients and rich in secondary metabolites (Nicolai, 1988; Ponge et al., 1997; Ponge et al., 1998). Studies on 
1 old-growth forests reveal that soil acidification under the influence of tree growth is temporary

2 and may reverse if environmental conditions and spatial configurations of habitats are proper

3 for the re-establishment of adapted decomposer communities (Ulrich, 1987; Bernier and

4 Ponge, 1994; Aubert et al., 2004). This occurs when nutrient requirements of the aboveground compartment of the forest ecosystem decrease after cessation of stem

6 elongation (Nilsson et al., 1982; Miller, 1984a; Chapin et al., 1986). Here we did not show

7 such reversal of the Humus Index in ageing stands, because our stands were probably too

8 young and occupied too large surfaces, in an otherwise intensively managed forest. The fact

9 that the relationship between age and Humus Index was linear (Fig. 2) indicates that the humus form changed steadily during stand development, at least during the first 90 years of crop rotation. The linear relationship between the Humus Index and the age of trees contradicts the hypothesis of stability domains within soil communities (Bengtsson, 2002;

13 Graefe, 2003; Ponge, 2003). According to this hypothesis, changes in soil communities

14 would occur by jumping from a species distribution to another, better adapted distribution, when the original community has been disrupted by an environmental stressor, such as for instance changes in environmental conditions and resource availability which occur during stand development. This should result in a discrete response of the Humus Index to tree growth, which was not depicted by our series of even-aged high forest stands.

The negative influence of beech upon soil biological activity was reflected in the 21 increase in Humus Index when the percent basal area occupied by beech increased (Table 22 1). Muys (1989) observed an increase in humus quality (expressed by an increase in earthworm biomass) and a decrease in soil compaction when beech was replaced by oak in 24 a Belgian forest. Similar results, using herb species as indicators of humus quality, were 25 obtained by Godefroid et al. (2005) in the same country. This phenomenon could be 26 explained by a higher increment in wood standing crop and basal area and a lower 27 decomposition rate of litter in beech compared to oak (Lemée and Bichaut, 1973; Monserud 
1 and Sterba, 1996), with concomitant soil impoverishment (Nilsson et al., 1982; Chapin et al., 2 1986).

The relationship between Humus Index and parameters of stand development (height, diameter at breast height, wood standing crop) can be mostly explained by stand age, as these parameters increase steadily during stand development (Miller, 1984b; Chapin et al., 1986; Ulrich, 1994). Stands resulting from the conversion of old coppices-withstandards compare well with 90-years-old even-aged high forest stands, the dominants of which are of the same height (25 m, see Fig. 3b), except that they reached a larger diameter at breast height (Fig. 3d), due to higher annual increments (Guilley et al., 2004) and probably older age. Both stand types exhibit a Humus Index averaging 4 (Dysmull). Howvever, coppices-with-standards show a high degree of variation in their stand characteristics, which are not correlated with the Humus Index (Figs. 3b, 3d, 3f, 3h). A more clear picture appears when soil types are taken into account. They explain most of the variation which remained unexplained by stand characteristics: both coppices-with-standards and even-aged high forest show a positive relationship between Humus Index and depth of clay horizon (Fig. 4b). When even-aged high forest trees are corrected for stand age, this relationship remains positive and significant, thus is not age-dependent, and differences between both forest types can be clearly perceived. For a given soil type, coppices-with-standards have a lower Humus Index (minus 0.5 unit) than oldest even-aged high forest stands. This means that 21 coppices-with-standards exhibit less litter accumulation even though they have a higher standing crop and the same basal area than even-aged high forest stands (Figs. $3 f$ and $3 \mathrm{~h}$ ). Given our knowledge of the relationships between humus forms (and closely related processes such as litter decomposition) and functional biodiversity of forest soils (Ponge et al., 1997; Ponge, 2003; Heemsbergen et al., 2004), we hypothesize that stands issuing from coppices-with-standards exhibit slightly more diversified animal and microbial communities than even-aged high forest. At first sight, this improvement of soil condition in converted coppices-with-standards could be explained by a higher diversity of woody vegetation, in 
1 particular to the presence of hornbeam in mixture with sessile oak, especially in the

2 understory (Aubert et al., 2004). However, in our study site we did not register any positive

3 influence of hornbeam upon the humus form (Table 1). Similarly, Bonneau and Ranger

4 (1984) observed a shift from Mull or Mull-Moder to Moder and a decrease in exchangeable cations when even-aged high forest stands were compared to coppices-with-standards in the Marchenoir forest, which is located not far from our study site. They attributed this shift to increased nutrient uptake and immobilization in the woody biomass of even-aged high forest, which impoverished the soil. Awaiting further studies, this interpretation could be questioned, because we observed that stands converted from coppices-with-standards neither exhibited a smaller basal area nor a smaller standing crop than even-aged high forest (Fig. 3). An alternative hypothesis could be that even-aged high forest trees were still too young to depict the improvement in soil biological activity (and thus the decrease in Humus Index) which is typically observed under older trees in natural forests (Page, 1974; Ponge et al., 1998).

14 Other comparisons with literature data, especially when climate conditions and tree composition are different, should be made with caution. For instance, Hölscher et al. (2001) concluded that soils from oak coppices exhibited less acidity and higher mineral pools than those from even-aged high forests, but the former group was made of oak while the latter was made of beech, which flawed the comparison.

The non-linear relationship between Humus Index and base availability (Fig. 4c-f) possibly indicates a trend towards a saturation of the ecosystem in exchangeable bases, in particular in the below-ground compartment which is chiefly responsible for the building of humus forms (Chapin et al., 1986). Some studies have shown that an increase in nutrient availability maybe ineffective in changing humus quality, if adapted decomposer communities and efficient foodwebs are not present or cannot build-up rapidly (Törne, 1978; Graefe, 1990; Muys and Lust, 1992). 
The observed stability of the Humus Index against thinning operations (Table 1),

2 despite a significant change in soil $\mathrm{pH}$ (see Results), can be ascribed to a redundancy 3 phenomenon within the humus profile, which has been explained in detail by Belotti and 4 Babel (1993). Each time a function (for instance the building of a horizon) is ensured by a variety of organisms, no pronounced change appears until the least sensitive species disappears (Heemsbergen et al., 2004). We hypothesize that the time from selection cutting to crown recovery is too short for destabilizing humus profiles, because of biological inertia, but also of the time required for building or disappearance of a horizon (Ulrich, 1987). A previous study on a spruce chronosequence showed that the increase in earthworm population size which accompanied thinning operations was only temporary and did not reverse the observed shift from Mull to Moder (Bernier and Ponge, 1994).

We are aware that, although exhibiting a number of significant trends when correlated with stand and soil variables, the Humus Index does not explain the whole variation of these conditions. Roughly, the Humus Index explains at best half the total variation of stand and soil parameters (Figs. 2 to 4). This could be explained by (i) the wide range of stand and soil types covered by our study, (ii) the existence of other, not accounted for, factors which may have influenced the building of humus forms. Among these factors, the past history of the stands is probably responsible for a significant part of the unexplained variation. Fire places for charcoal production, agricultural past, human settlements, among others, are known to affect the distribution of plant species, which is probably true of soil organisms, too (Koerner et al., 1997). Even though we can discard agricultural past in the case of the studied forest, other human influences should not be neglected.

\section{Conclusion}

We showed that the Humus Index can be correlated with several important parameters of stand development and soil type, pointing on its possible use in the 
1 assessment of site quality and the long-term survey of ecosystems. Awaiting further

2 theoretical and experimental developments, the Humus Index should be considered as a

3 synthetic measurement of the complexity of soil communities (Ponge, 2003), which could be

4 used as an early tool to predict changes at the ecosystem level, due to tree growth,

5 management pratices, climate change and pollution. Practicability of the method cannot be

6 questioned, since it does not need any other measurement than the estimate by eye of

7 horizons and structures. The only point which deserves further elaboration is a possible shift

8 from person to person in the estimate of horizon thickness, which has been highlighted by

9 Federer (1982). A standardization of the method would alleviate such possible biases.

10 Further studies should also take into account between-forest variation and the time required

11 fro reaching an equilibrium in the humus type (Wilson et al., 2001), before reaching firm

12 conclusions about the use of the Humus Index for ecological site classification (Ray, 2001).

13

14 Acknowledgements

15

The authors acknowledge the Centre d'Études du Machinisme Agricole et du Génie

Rural des Eaux et Forêts (Cemagref) for financial support and the Office National des Forêts (ONF) for field facilities.

\section{References}

Aber, J.D., Botkin, D.B., Melillo, J.M., 1978. Predicting the effects of different harvesting regimes on forest floor dynamics in northern hardwoods. Can. J. For. Res. 8, 306315.

Adam, M., 1999. Nutrient fluctuations in Sitka spruce (Picea sitchensis) plantations: the implications for future forest management practice. Forestry $72,249-271$. 
1 Anonymous, 1999. Qualité des Sols. AFNOR, Paris.

Aubert, M., Bureau, F., Alard, D., Bardat, J., 2004. Effect of tree mixture on the humic epipedon and vegetation diversity in managed beech forests (Normandy, France). Can. J. For. Res. 34, 233-248.

6

Bartoli, M., Tran-Ha, M., Largier, G., Dumé, G., Larrieu, L., 2000. ECOFLORE, un logiciel simple de diagnostic écologique. Rev. For. Fr. 52, 530-546.

Belotti, E., Babel, U., 1993. Variability in space and time and redundancy as stabilizing principles of forest humus profiles. Eur. J. Soil Biol. 29, 17-27.

Bengtsson, J., 2002. Disturbance and resilience in soil animal communities. Eur. J. Soil Biol. 38, 119-125.

15

Beniamino, F., Ponge, J.F., Arpin, P., 1991. Soil acidification under the crown of oak trees. I. Spatial distribution. For. Ecol. Manag. 40, 221-232.

Bernier, N., 1996. Altitudinal changes in humus form dynamics in a spruce forest at the montane level. Plant Soil 178, 1-28.

Bernier, N., Ponge, J.F., 1994. Humus form dynamics during the sylvogenetic cycle in a mountain spruce forest. Soil Biol. Biochem. 26, 183-220.

Bonneau, M., Ranger, J., 1984. Effect of an oak forest on a silty acid soil. Changes in humus form and exchangeable cations. In: Ågren, G.I. (Ed.), State and Change of Forest Ecosystems. Indicators in Current Research. Swedish University of Agricultural 
Sciences, Department of Ecology and Environmental Research, Report N¹3, pp. 245-249.

Brêthes, A., Brun, J.J., Jabiol, B., Ponge, J.F., Toutain, F., 1995. Classification of forest humus forms: a French proposal. Ann. Sci. For. 52, 535-546.

Carmean, W.H., 1975. Forest site quality evaluation in the United States. Adv. Agron. 27, 209-269.

Carter, R.E., Lowe, L.E., 1986. Lateral variability of forest floor properties under secondgrowth Douglas-fir stands and the usefulness of composite sampling techniques. Can. J. For. Res. 16, 1128-1132.

Chapin, F.S. III, Vitousek, P.M., Van Cleve, K., 1986. The nature of nutrient limitation in plant communities. Am. Nat. 127, 48-58.

Christie, J.M., Lines, R., 1979. A comparison of forest productivity in Britain and Europe in relation to climatic factors. For. Ecol. Manag. 2, 75-102.

Coughtrey, P.J., Jones, C.H., Martin, M.H., Shales, S.W., 1979. Litter accumulation in woodlands contaminated by $\mathrm{Pb}, \mathrm{Zn}, \mathrm{Cd}$ and $\mathrm{Cu}$. Oecologia 39, 51-60.

Covington, W.W., 1981. Changes in forest floor organic matter and nutrient content following clear cutting in northern hardwoods. Ecology 62, 41-48.

Dagnélie, P., Palm, R., Rondeux, J., Thill, A., 1999. Tables de Cubage des Arbres et des Peuplements Forestiers. Les Presses Agronomiques de Gembloux, Gembloux. 
1 Davies, R.I., Coulson, C.B., Lewis, D.A., 1964. Polyphenols in plant, humus, and soil. IV. Factors leading to increase in biosynthesis of polyphenol in leaves and their relationship to mull and mor formation. J. Soil Sci. 15, 310-318.

Delecour, F., 1978. Facteurs édaphiques et productivité forestière. Pédologie 28, 271-284.

Deleporte, S., Tillier, P., 1999. Long-term effects of mineral amendments on soil fauna and humus in an acid beech forest floor. For. Ecol. Manag. 118, 245-252.

Diekmann, M., Lawesson, J.E., 1999. Shifts in ecological behaviour of herbaceous forest species along a transect from northern Central to North Europe. Folia Geobot. 34, 127-141.

Duelli, P., Obrist, M.K., 2003. Biodiversity indicators: the choice of values and measures. Agr. Ecosyst. Env. 98, 87-98.

Ellenberg, H., 1974. Zeigerwerte der Gefasspflanzen Mitteleuropas. Scripta Geobotanica 9, $1-97$.

Emmer, I.M., Sevink, J., 1994. Temporal and vertical changes in the humus form profile during a primary succession of Pinus sylvestris. Plant Soil 167, 281-295.

Federer, C.A., 1982. Subjectivity in the separation of organic horizons of the forest floor. Soil Sci. Soc. Am. J. 46, 1090-1093.

Fédoroff, E., Ponge, J.F., Dubs, F., Fernández-González, F., Lavelle, P., 2005. Small-scale response of plant species to land use intensification. Agr. Ecosyst. Environ. 105, 283290. 
2 Garnier, A., 1965. La forêt de Montargis. Excursion du 4 avril 1965. Bull. Assoc. Naturalistes Orléanais 30-7, $12-23$.

4

5 Gillet, S., Ponge, J.F., 2002. Humus forms and metal pollution in soil. Eur. J. Soil Sci. 53, 6 529-539.

7

Godefroid, S., Massant, W., Koedam, N., 2005. Variation in the herb species response and the humus quality across a 200-year chronosequence of beech and oak plantations in Belgium. Ecography 28, 223-235.

11

Graefe, U., 1990. Untersuchungen zum Einfluß von Kompensationskalkung und Bodenbearbeitung auf die Zersetzerfauna in einem bodensauren Buchenwald- und Fichtenforst-Ökosystem. In: Gehrmann, J. (Ed.), Umweltkontrolle am Waldökosystem.

Graefe, U., 2003. Spatial variety of soil biota: diversity of types vs. diversity of species. Verhandl. Gesellsch. Ökol. 33, 405. Forsch. Berat. C 48, 232-241.

\section{2}

Guilley, E., Hervé, J.C., Nepveu, G., 2004. The influence of site quality, silviculture and region on wood density mixed model in Quercus petraea Liebl. For. Ecol. Manag. 189, 111-121. 
1 Heemsbergen, D.A., Berg, M.P., Loreau, M., Van Hal, J.R., Faber, J.H., Verhoef, H.A., 2004. Biodiversity effects on soil processes explained by interspecific functional dissimilarity. Science 306, 1019-1020.

4

Hill, M.O., Mountford, J.O., Roy, D.B., Bunce, R.G.H., 1999. Ellenberg's Indicator Values for British Plants. Ministry of Agriculture, Fisheries and Food, Department of the Environment, Transport and the Regions, London.

Hölscher, D., Schade, E., Leuschener, C., 2001. Effects of coppicing in temperate deciduous forests on ecosystem nutrient pools and soil fertility. Basic Appl. Ecol. 2, 155-164.

11

Jabiol, B., Höltermann, A., Gégout, J.C., Ponge, J.F., Brêthes, A., 2000. Typologie des

Klinka, K., Wang, Q., Carter, R.E., 1990. Relationships among humus forms, forest floor nutrient properties, and understory vegetation. For. Sci. 36, 564-581.

Koerner, W., Dupouey, J.L., Dambrine, E., Benoît, M., 1997. Influence of past land use on the vegetation and soils of present day forest in the Vosges mountains, France. J. Ecol. 85, 351-358.

Kuperman, R.G., 1996. Relationships between soil properties and community structure of soil macroinvertebrates in oak-kickory forests along an acidic deposition gradient. Appl. Soil Ecol. 4, 125-137. 
1 Lemée, G., Bichaut, N., 1973. Recherches sur les écosystèmes des réserves biologiques de la forêt de Fontainebleau. II. Décomposition de la litière de feuilles des arbres et libération des bioéléments. Oecol. Plant. 8, 153-174.

Le Tacon, F., Timbal, J., 1973. Valeurs indicatrices des principales espèces végétales des hêtraies du Nord-Est de la France vis-à-vis des types d'humus. Rev. For. Fr. 25, 269282.

Lindenmayer, D.B., Margules, C.R., Boykin, D.B., 2000. Indicators of biodiversity for ecologically sustainable forest management. Conserv. Biol. 14, 941-950.

Miller, H.G., 1981. Forest fertilization: some guiding concepts. Forestry 54, 157-167.

Miller, H.G., 1984a. Nutrient cycles in birchwoods. Proc. Roy. Soc. Edinburgh 85B, 83-96.

Miller, H.G., 1984b. Dynamics of nutrient cycling in plantation ecosystems. In: Bowen, G.D., Nambiar, E.K.S. (Eds.), Nutrition of Forest Trees in Plantations. Academic Press, London, pp. 53-78.

Monserud, R.A., Sterba, H., 1996. A basal area increment model for individual trees growing in even- and uneven-aged forest stands in Austria. For. Ecol. Manag. 80, 57-80.

Moore, J.C., DeRuiter, P.C., 1993. Assessment of disturbance on soil ecosystems. Vet. Parasit. 48, 75-85.

Muys, B., 1989. Evaluation of conversion of tree species and liming as measures to decrease soil compaction in a beech forest on loamy soil. In: Actes du Séminaire sur les Conséquences de la Mécanisation des Opérations Forestières sur le Sol, 
Louvain-la-Neuve, Belgium, 11-15 September 1989. Ministère de l'Agriculture, Brussel, pp. 341-355.

Muys, B., Lust, N., 1992. Inventory of the earthworm communities and the state of litter decomposition in the forests of Flanders, Belgium, and its implications for forest management. Soil Biol. Biochem. 24, 1677-1681.

Muys, B., Lust, N., Granval, P., 1992. Effects of grassland afforestation with different tree species on earthworm communities, litter decomposition and nutrient status. Soil Biol. Biochem. 24, 1459-1466.

Nicolai, V., 1988. Phenolic and mineral content of leaves influences decomposition in European forest ecosystems. Oecologia 75, 575-579.

Nilsson, S.I., Miller, H.G., Miller, J.D., 1982. Forest growth as a possible cause of soil and water acidification: an examination of the concepts. Oikos 39, 40-49.

Odum, E.P., 1969. The strategy of ecosystem development. Science 164, 262-270.

Ovington, J.D., 1965. Organic production, turnover and mineral cycling in woodlands. Biol. Rev. 40, 295-336.

Page, G., 1974. Effects of forest cover on the properties of some Newfoundland forest soils. Can. For. Serv. Dept Environ. Publ. 1332, 1-32.

Parrish, J.A.D., Bazzaz, F.A., 1985. Ontogenetic niche shifts in old-field annuals. Ecology 66, 1296-1302. 
1 Perry, D.A., Amaranthus, M.P., Borchers, J.G., Brainerd, R.E., 1989. Bootstrapping in ecosystems. BioScience 39, 230-237.

Ponge, J.F., 2003. Humus forms in terrestrial ecosystems: a framework to biodiversity. Soil Biol. Biochem. 35, 935-945.

6

Ponge, J.F., André, J., Zackrisson, O., Bernier, N., Nilsson, M.C., Gallet, C., 1998. The forest regeneration puzzle. BioScience 48, 523-530.

9

Ponge, J.F., Arpin, P., Sondag, F., Delecour, F., 1997. Soil fauna and site assessment in beech stands of the Belgian Ardennes. Can. J. For. Res. 27, 2053-2064.

Ponge, J.F., Chevalier, R., Loussot, P., 2002. Humus Index: an integrated tool for the assessment of forest floor and topsoil properties. Soil Sci. Soc. Am. J. 66, 1996-2001.

Ponge, J.F., Delhaye, L., 1995. The heterogeneity of humus profiles and earthworm communities in a virgin beech forest. Biol. Fertil. Soils 20, 24-32.

Ponge, J.F., Gillet, S., Dubs, F., Fédoroff, E., Haese, L., Sousa, J.P., Lavelle, P., 2003. Collembolan communities as bioindicators of land use intensification. Soil Biol.

Ray, D., 2001. An Ecological Site Classification for Forestry in Great Britain. Forestry Biochem. 35, 813-826.

Riha, S.J., James, B.R., Senesac, G.P., Pallant, E., 1986. Spatial variability of soil pH and Commission, Bulletin No 124. 
1 Sadaka, N., Ponge, J.F., 2003. Climatic effects on soil trophic networks and the resulting humus profiles in holm oak (Quercus rotundifolia) forests in the High Atlas of Morocco as revealed by correspondence analysis. Eur. J. Soil Sci. 54, 767-777.

4

Sagot, C., Brun, J.J., Grossi, J.L., Chauchat, J.H., Boudin, G., 1999. Earthworm distribution and humus forms in the development of a semi-natural alpine spruce forest. Eur. J. Soil Biol. 35, 163-169.

Sokal, R.R., Rohlf, F.J., 1995. Biometry. The Principles and Practice of Statistics in Biological Research. Freeman, New York.

Terlinden, M., André, P., 1988. Effets de l'intensité d'éclaircie sur les horizons organiques et hémiorganiques du sol en futaie équienne de Picea abies. Pedobiologia 32, 201-309.

Torgersen, C.E., Jones, J.A., Moldenke, A.R., LeMaster, M.P., 1995. The spatial heterogeneity of soil invertebrates and edaphic properties in an old growth forest stand in western Oregon. In: Collins, H.P., Robertson, G.P., Klug, M.J. (Eds.), The Significance and Regulation of Soil Biodiversity. Kluwer, Dordrecht, pp. 225-236.

von Törne, E., 1978. Experimenteller Nachweis zootischer Einflüsse auf den Stoffumsatz in einem Kiefernforst. Pedobiologia 18, 398-414.

Toutain, F., Diagne, A., Le Tacon, F., 1988. Possibilités de modification du type d'humus et d'amélioration de la fertilité des sols à moyen terme en hêtraie par apport d'éléments minéraux. Rev. For. Fr. 40, 99-107.

Toutain, F., Duchaufour, P., 1970. Étude comparée des bilans biologiques de certains sols de hêtraie. Ann. Sci. For. 27, 39-61. 
2 Ulrich, B., 1987. Stability, elasticity, and resilience of terrestrial ecosystems with respect to matter balance. In: Schulze, E.D., Zwölfer, H. (Eds.), Potentials and Limitations of Ecosystem Analysis. Ecol. Stud. 61, 11-49.

5

6 Ulrich, B., 1994. Process hierarchy in forest ecosystems: an integrative ecosystem theory. In: Hutterman, A., Godbold, D. (Eds.), Effects of Acid rain on Forest Processes. WileyLiss, New York, pp. 353-397.

9

Vavoulidou-Theodorou, E., Babel, U., 1987. Ein Bewässerungsversuch zur Dynamik von Humusprofilen in Nadelholsbeständen mit Wuchsstörung. Pedobiologia 30, 389-399.

Vitousek, P.M., Turner, D.R., Parton, W.J., Sanford, R.L., 1994. Litter decomposition of the Mauna Loa environmental metrix, Hawai'i: patterns, mechanisms and models. Ecology 75, 418-429.

16

Wilson, S.McG., Pyatt, D.G., Malcolm, D.C., Connolly, T., 2001. The use of ground vegetation and humus type as indicators of soil nutrient regime for an ecological site classification of British forests. For. Ecol. Manag. 140, 101-116. 


\section{$1 \quad$ Figure captions}

2

3 Fig. 1. Location map of the Montargis forest (France)

4

5 Fig. 2. Relationship between Humus Index and age of even-aged high forest stands. ${ }^{* *}=$ 6 significant at 0.001 level ( $F$ test)

7

Fig. 3. Relationship between Humus Index and four stand measurements. N.S. = not significant; ${ }^{* *}=$ significatn at 0.01 level; ${ }^{* *}=$ significant at 0.001 level $(F$ test $)$

Fig. 4. Relationship between Humus Index and three soil measurements. ${ }^{* *}=$ significant at 0.01 level; ${ }^{* * *}=$ significant at 0.001 level $(\mathrm{F}$ test $)$

13 
Table 1. Main features of the 96 selected stands. The percent presence of the three main tree species refers to the total basal area. The time since the last thinning operation is expressed in years

\begin{tabular}{|c|c|}
\hline Code number & Forest type \\
\hline 1 & even-aged high forest \\
\hline 2 & even-aged high forest \\
\hline 3 & even-aged high forest \\
\hline 10 & even-aged high forest \\
\hline 12 & even-aged high forest \\
\hline 13 & even-aged high forest \\
\hline 17 & even-aged high forest \\
\hline 18 & even-aged high forest \\
\hline 19 & even-aged high forest \\
\hline 20 & even-aged high forest \\
\hline 21 & even-aged high forest \\
\hline 23 & even-aged high forest \\
\hline 25 & even-aged high forest \\
\hline 26 & even-aged high forest \\
\hline 27 & even-aged high forest \\
\hline 28 & even-aged high forest \\
\hline 29 & even-aged high forest \\
\hline 34 & even-aged high forest \\
\hline 36 & even-aged high forest \\
\hline 37 & even-aged high forest \\
\hline 38 & even-aged high forest \\
\hline 39 & even-aged high forest \\
\hline 40 & even-aged high forest \\
\hline 41 & even-aged high forest \\
\hline 42 & even-aged high forest \\
\hline 43 & even-aged high forest \\
\hline 44 & even-aged high forest \\
\hline 47 & even-aged high forest \\
\hline 48 & even-aged high forest \\
\hline 49 & even-aged high forest \\
\hline 50 & even-aged high forest \\
\hline 51 & even-aged high forest \\
\hline 54 & converted coppice-with-standards \\
\hline 55 & converted coppice-with-standards \\
\hline 57 & converted coppice-with-standards \\
\hline 58 & converted coppice-with-standards \\
\hline 59 & converted coppice-with-standards \\
\hline 60 & converted coppice-with-standards \\
\hline 62 & converted coppice-with-standards \\
\hline 63 & converted coppice-with-standards \\
\hline 64 & converted coppice-with-standards \\
\hline 65 & converted coppice-with-standards \\
\hline 66 & converted coppice-with-standards \\
\hline 68 & converted coppice-with-standards \\
\hline 69 & converted coppice-with-standards \\
\hline 75 & converted coppice-with-standards \\
\hline 76 & converted coppice-with-standards \\
\hline 77 & converted coppice-with-standards \\
\hline 79 & converted coppice-with-standards \\
\hline 83 & converted coppice-with-standards \\
\hline 84 & converted coppice-with-standards \\
\hline 86 & converted coppice-with-standards \\
\hline 87 & converted coppice-with-standards \\
\hline 90 & converted coppice-with-standards \\
\hline 91 & converted coppice-with-standards \\
\hline 92 & converted coppice-with-standards \\
\hline 93 & converted coppice-with-standards \\
\hline 96 & converted coppice-with-standards \\
\hline 98 & converted coppice-with-standards \\
\hline 99 & converted coppice-with-standards \\
\hline 100 & converted coppice-with-standards \\
\hline 101 & converted coppice-with-standards \\
\hline 102 & converted coppice-with-standards \\
\hline 103 & converted coppice-with-standards \\
\hline 105 & converted coppice-with-standards \\
\hline 106 & converted coppice-with-standards \\
\hline 109 & converted coppice-with-standards \\
\hline 114 & converted coppice-with-standards \\
\hline 115 & converted coppice-with-standards \\
\hline 116 & converted coppice-with-standards \\
\hline 117 & converted coppice-with-standards \\
\hline 119 & converted coppice-with-standards \\
\hline 128 & converted coppice-with-standards \\
\hline 129 & converted coppice-with-standards \\
\hline 130 & converted coppice-with-standards \\
\hline 131 & converted coppice-with-standards \\
\hline 132 & even-aged high forest \\
\hline 133 & even-aged high forest \\
\hline 135 & even-aged high forest \\
\hline 136 & even-aged high forest \\
\hline 138 & even-aged high forest \\
\hline 140 & even-aged high forest \\
\hline 141 & even-aged high forest \\
\hline 143 & even-aged high forest \\
\hline 144 & even-aged high forest \\
\hline 145 & even-aged high forest \\
\hline 147 & even-aged high forest \\
\hline 148 & even-aged high forest \\
\hline 152 & even-aged high forest \\
\hline 153 & even-aged high forest \\
\hline 155 & even-aged high forest \\
\hline 156 & even-aged high forest \\
\hline 158 & converted coppice-with-standards \\
\hline 159 & converted coppice-with-standards \\
\hline 160 & converted coppice-with-standards \\
\hline 167 & converted coppice-with-standards \\
\hline
\end{tabular}


Table 2. Product-moment correlation coefficients between Humus Index, $\mathrm{pH}_{\text {water }}$ and main parameters describing stand and soil condition. Correlation coefficients were tested by $t$ test. Significance levels are: ${ }^{*}=0.05,{ }^{* *}=0.01,{ }^{* * *}=0.001$. Degrees of freedom $=94$, except for stand age (46) and time from last thinning operation (82)

\begin{tabular}{|c|c|c|}
\hline & Humus Index & $\mathrm{pH}_{\text {water }}$ \\
\hline Time from last thinning operation & $0.10 \mathrm{NS}$ & $-0.27^{* *}$ \\
\hline Age of the stand & $0.73^{* \star *}$ & $0.05 \mathrm{NS}$ \\
\hline Height of the three dominant trees & $0.61^{* \star *}$ & $-0.35^{\star \star *}$ \\
\hline Diameter at breast height of the three dominant trees & $0.64^{\star * *}$ & $-0.46^{\star \star *}$ \\
\hline Basal area & $0.41^{\star * *}$ & $-0.13 \mathrm{NS}$ \\
\hline$\%$ basal area occupied by beech & $0.29^{* \star}$ & $-0.20 \mathrm{NS}$ \\
\hline$\%$ basal area occupied by hornbeam & $0.21^{*}$ & $-0.16 \mathrm{NS}$ \\
\hline Wood standing crop & $0.59^{\star * *}$ & $-0.34^{\star \star *}$ \\
\hline Depth of the first enrichment in clay & $0.43^{\star \star *}$ & $0.04 \mathrm{NS}$ \\
\hline Depth of the first clay-dominated horizon & $0.47^{* \star *}$ & $-0.05 \mathrm{NS}$ \\
\hline$\%$ clay & $-0.21^{*}$ & $-0.31^{* *}$ \\
\hline$\%$ silt & $-0.19 \mathrm{NS}$ & $-0.40^{* * *}$ \\
\hline$\%$ sand & $0.20 \mathrm{NS}$ & $0.38^{* * *}$ \\
\hline $\mathrm{pH}_{\text {water }}$ & $-0.39^{\star \star *}$ & \\
\hline $\mathrm{pH}_{\mathrm{KCl}}$ & $0.12 \mathrm{NS}$ & $0.58^{* * *}$ \\
\hline Cation exchange capacity & $-0.25^{\star}$ & $-0.27^{\star *}$ \\
\hline Exchangeable $\mathrm{Ca}$ & $-0.51^{\star \star \star}$ & $0.45^{\star * *}$ \\
\hline Exchangeable Mg & $-0.38^{* * *}$ & $0.13 \mathrm{NS}$ \\
\hline Exchangeable $\mathrm{K}$ & $-0.29^{* *}$ & $-0.09 \mathrm{NS}$ \\
\hline Total exchangeable bases & $-0.50^{* \star *}$ & $0.39^{* * *}$ \\
\hline Base saturation & $-0.61^{* \star *}$ & $0.68^{\star \star *}$ \\
\hline
\end{tabular}




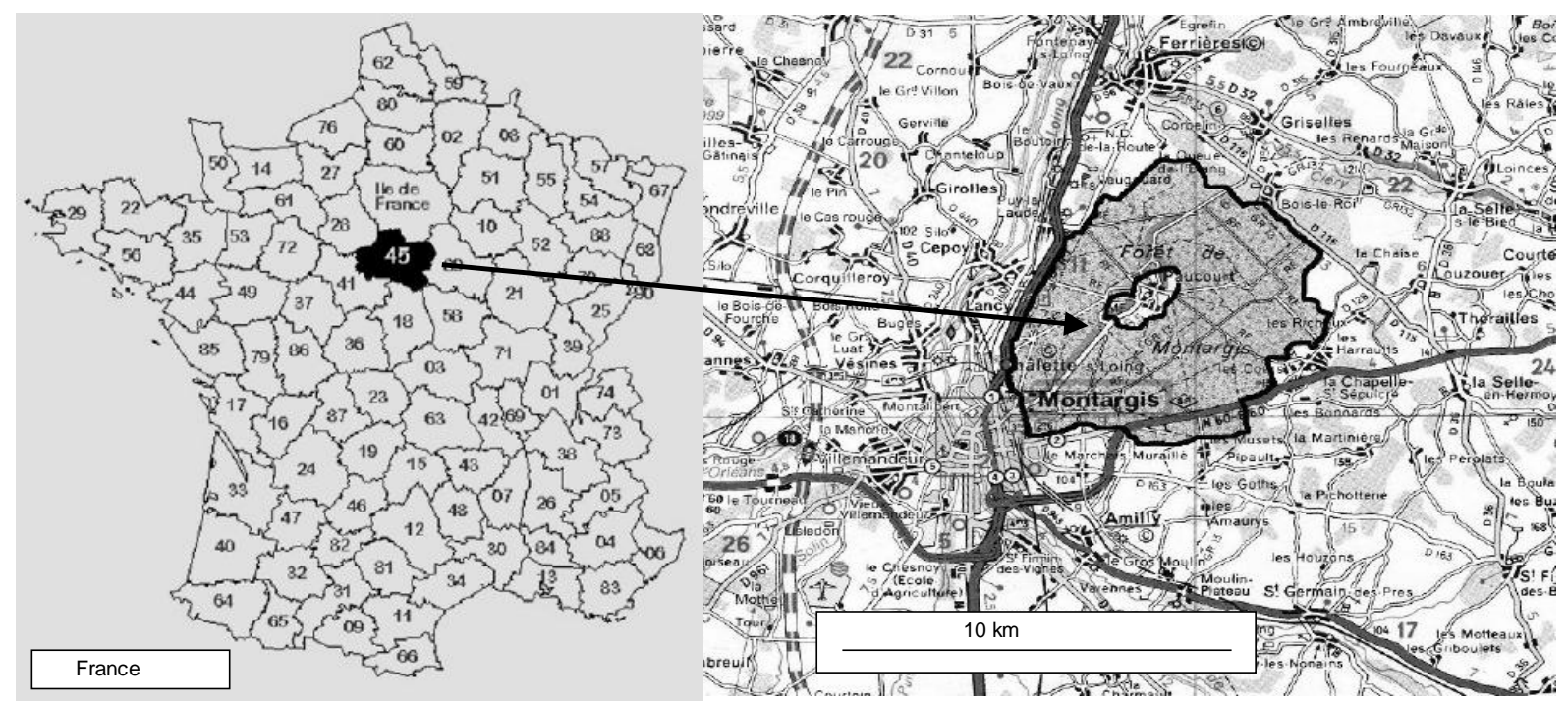

Fig. 1 


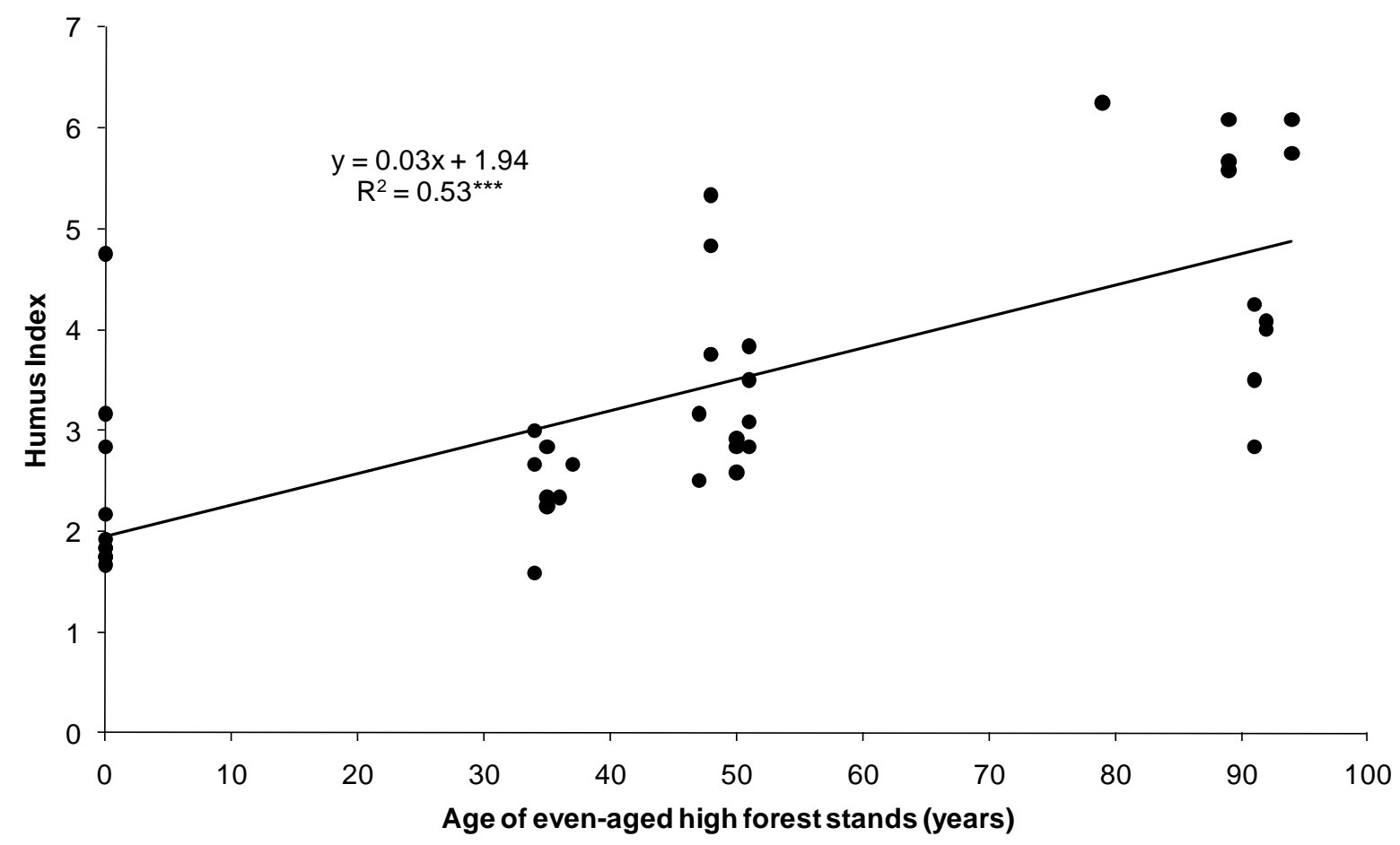

2 Fig. 2

3 

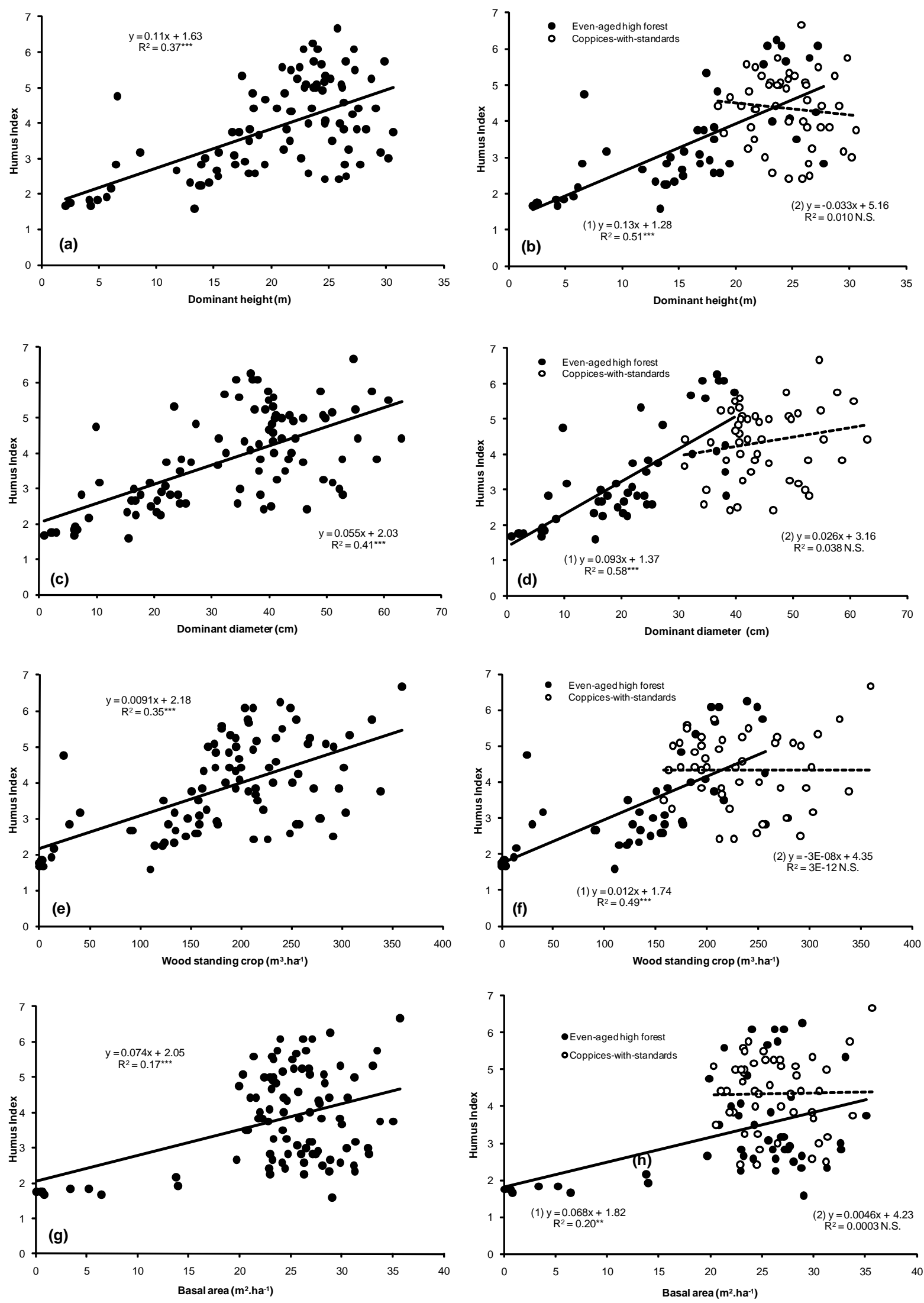

Fig. 3 

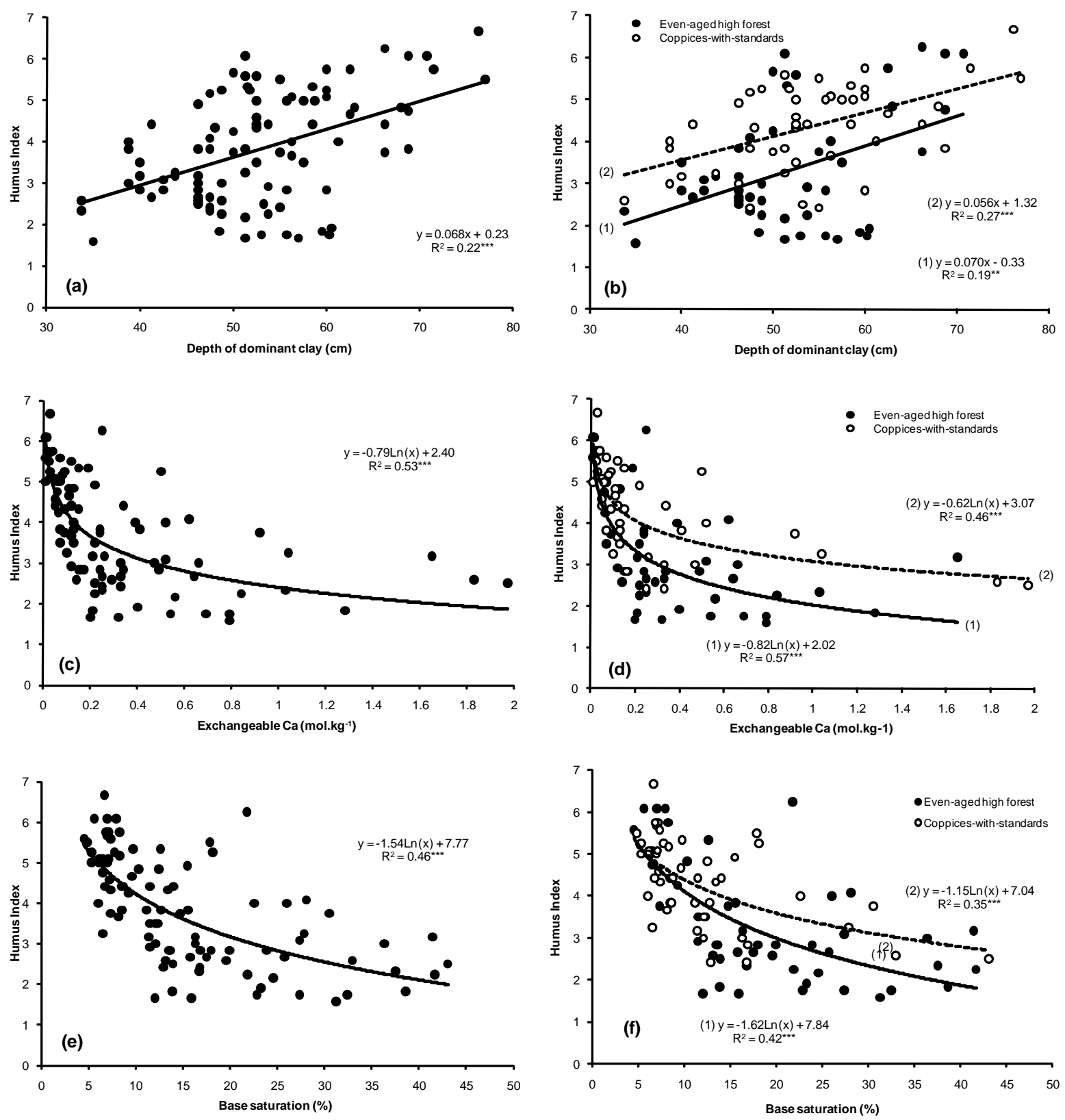

2 Fig. 4 